\title{
PROSPECTUS FOR THE FURTHER STUDY OF FEDERAL ADMINISTRATIVE LAW
}

\author{
BY A. H. FELLER $†$
}

The system of administrative adjudication has been with us a long time. We can leave aside the Statute of Sewers enacted under Henry VIII $^{1}$ and other ancient examples ${ }^{2}$ and merely point out that the Interstate Commerce Commission is more than fifty years old, ${ }^{3}$ the Federal Trade Commission more than twenty, ${ }^{4}$ and that many of the quasijudicial and quasi-legislative functions of federal officials reach bacl: for many decades. ${ }^{5}$ With all this history behind us, the legal profession still lacks the knowledge on which any true understanding can be based. Doubtless there are few lawyers who are not now convinced of the necessity of the system. Yet a large portion of the bench and bar continues to display an attitude of suspicion, if not of hostility. A small group of devoted scholars of administrative law have divided their attention between writing apologies for the system and studying in elaborate detail the relations between administrative tribunals and the common-law courts. The necessity of these tasks and the great value of the work of these men cannot be overestimated. Yet, in the struggle to justify the system as a whole, its actual workings have, with a few exceptions, ${ }^{\circ}$ not been explored. Between violent denunciations and eloquent defense of general principles the gathering of detailed knowledge and the improvement of efficiency languish. Legislative draftsmen continue to copy slavishly the procedural provisions of old statutes, since they have no means of determining how those provisions can be improved. The courts, often knowing but little of the administrative process, are prone either to abdicate their legitimate

iVisiting Lecturer, Harvard Law School.

1. 23 HEN. VIII, c. 5 (1531).

2. See Report of the Committee on Armisters' Powers (1932 Cmd. 4060) 8 et seq.; Robson, Justice and Adurnistrative Lav (1928) c. 1.

3. The Interstate Commerce Commission was established by the Act of February 4, 1887, 24 StaT. 379, 49 U.S.C.A. \$11 (1934).

4. The Federal Trade Commission was established by the Act of Septembar 25, 1914, 38 STAT. 717, 15 U. S. C. A. $\$ 41$ (1934).

5. Some of these functions date back to the beginning of our history. One of the earliest federal statutes authorized the collectors of customs to allow drawbaclss of duties on presentation of proper proof. Act of July 31, 1789, 1 Srar. 29, §32.

6. At the head of this category must be placed Hendenson, Tre Fenezar Trade Conrarission (1924) and Sharfican, The Interstate Cozorerce Counrission (193138). See also McFartand, The Interstate Cozsuerce Coznsission aitd the Fenerar. Trade Courarission (1933); StepHens, Adumnistrative Triduinals aito trie Rules

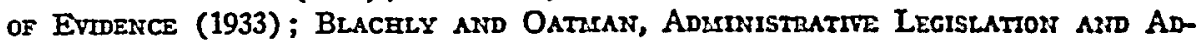
judrcation (1934); Nagel, Federal Deparimental Practice, The Growte or Auresicas ADMINISTRATIVE LAW (1923) 175. 
functions of control and to rubber-stamp administrative action, or, where their emotions are aroused, to strike out blindly without regard for the damage which may ensue.

If proof be needed of the dangers of this situation, two recent instances will be found sufficient, the decision of the United States Supreme Court in Jones v. Securities and Exchange Commission, ${ }^{7}$ and the proposal of a committee of the American Bar Association to establish a United States Administrative Court. ${ }^{8}$ In the Jones case the Supreme Court adopted an emotional approach to a technical problem of procedure and, in its anxiety to save a single securities issuer from the supposedly arbitrary actions of a Commission, delivered an opinion the consequences of which may sweep away the safeguards carefully designed by Congress to protect securities issuers as a whole from precisely the arbitrary action which the Court professed to fear. ${ }^{9}$ The proposal for an administrative court exhibits the same sort of distrust of, as well as failure to understand, the administrative process. ${ }^{10}$ Yet this suggestion to superimpose a gargantuan court

7. 298 U. S. 1 (1936).

.8. The proposal was embodied in the Logan Bill, S.3787, 74th Congo, 2nd Sess. (1936). The plan contemplated an Administrative Court to consist of a Chief Justice and forty associate justices appointed for life. The Cour ${ }^{2}$ of Claims, the Court of Customs and Patent Appeals, the Customs Court, and the Board of Tax Appeals were to be abolished and all their members transferred to the new court as associate justices. The court was to consist of a trial division and of an appellate division. Three stages of procedure were provided for: The trial division was to try the facts in any proceeding. Appeal might then be had to the appellate division, which was to have jurisdiction to review all matters appearing on the record, including both questions of law and of fact, and which in its discretion might also permit or direct the taking of additional evidence. In other words, the appellate division might in all cases grant a trial de novo. A further appeal was provided from the decision of the appellate division to the appellate division sitting en banc, its jurisdiction being limited to questions of law. Final revicw would be the Supreme Court on certiorari.

The jurisdiction of the court was to include: (1) The jurisdiction now vested in the Court of Customs and Patent Appeals, the Court of Claims, the Customs Court, and the Board of Tax Appeals, (2) the jurisdiction of the United States District Courts over actions against Collectors of Internal Revenue for the recovery of taxes and over suits to enjoin the collection of taxes, (3) the jurisdiction of the District Court of the District of Columbia in proceedings of extraordinary processes against officers and employees of the United States, (4) jurisdiction to review the action of any governmental agency in refusing to admit any person to practice before it or on disbarment from practice, and (5) the extensive jurisdiction now vested in any governmental agencies over the revocation of licenses, permits, registrations or other grants for regulatory purposes.

9. See the further discussion of this case, p. 670 , infra.

10. The administrative court proposal has called forth a good deal of discussion. See McGuire, Sailing Close to the Wind, or the Need for a Federal Administrative Court (1936) 22 A. B. A. J. 853; Cooper, The Proposed United States Administratiz'e Court (1936) 35 Mich. L. Rev. 193, 565; Caldwell, A Federal Administrative Court (1936) 84 U. of PA. L. Rev. 966. The Committee which proposed this plan has since 
of vague contours and of no demonstrable utility on top of the existing congeries of agencies was devised by a group of experienced and sophisticated practitioners before administrative tribunals.

The task of the students of administrative law must be to learn what the existing administrative tribunals are doing, what their remediable defects are, what should be preserved and what discarded. This cannot be done merely by scanning statutes and cases in the law reports. It cannot be done by proceeding on a priori assumptions as to what the proper thing is. It cannot be done by appointing a committee, however learned and eminent, which will look the field over for a month or two and then render a report. It can only be done by the assiduous application of scholars who have the time and energy to plunge into masses of files, to talk to scores of men engaged in administration, and to think out their conclusions on the basis of adequate information. Of course, there is nothing new about this approach. The Commonwealth. Fund recognized the problem as long ago as 1920 when Gerald Henderson was commissioned to write his The Federal Trade Commission. Students of administrative law know this book to be a landmark; yet more than fifteen years have passed and only a few comparable works have been produced. In the intervening years the administrative machine has become more and more complex and tie problems more and more pressing. A revivification and intensification of these earlier efforts are earnestly needed.

It is my purpose here to set forth a few of the problems to which the further study of administrative law must be directed and to offer a few suggestions of an experimental nature for furthering the progress of this study. None of the problems propounded are answered here. Many of them cannot be satisfactorily answered in the present state of our knowledge. But they constitute the critical points of administrative law today, and they must be answered in the near future.

\section{Organizational Problears}

The problem which precedes all others is what form the agency engaged in administrative adjudication and legislation should take. We are here concerned with those activities of administrative agencies which have to do (a) with the promulgation of regulations goverriaty certain conduct of groups of private persons, these regulations having the force of law, ${ }^{11}$ and (b) with adjudications of the rights of private persons.

abandoned it. See its report in Advance Programs of the COtr Alisual Merthic of the Ayrerican Bar Association (1937) at 183-186.

11. These regulations constitute what has been called "delegated legislation" [Report of the Comarrteee on Ministers' Powers, op. cit. supra note 2, at 15] and are to be distinguished from regulations dealing with internal management of an agency, c.g., regulations on the preparation of correspondence, conduct of employees, etc. Hereafter the term "regulations" will be used only in the first sense. 
The first activity, often known as quasi-legislative, we will call "legislative;" the second activity, often known as judicial and quasi-judicial, ${ }^{12}$ we will call "adjudicative." 13

Several writers have recently attempted classification of the existing types of these activities in the Federal Government. ${ }^{14}$ Whether such classifications have any validity is a matter on which we may have considerable doubt. Still, for purposes of exposition, it may be useful to go over this ground again.

1. Legislative powers of executive departments. Nearly every executive department has power to issue regulations. Some of the more striking examples are the tax regulations issued by the Treasury, ${ }^{16}$ the "orders" regulating the handling of agricultural commodities issued by the Secretary of Agriculture under the Agricultural Adjustment Act, ${ }^{10}$ and regulations issued by the Secretary of Commerce under the Air Commerce Act. ${ }^{17}$ The President is also entrusted with numerous powers to issue regulations. ${ }^{18}$

2. Legislative powers of independent agencies. Two types of independent agencies have legislative powers: one type is the purely regulatory agency, typified by the Securities and Exchange Commission; ${ }^{10}$

12. On the distinction between "judicial" and "quasi-judicial" see id., at 73-75.

13. Like most distinctions, this one is to a large extent artificial. It is easy to call to mind many cases which may fall into either category in accordance with individual points of view. From the standpoint of the courts, however, the distinction, whatever the precise line of demarcation between the two categories, is important. For some illustrations, see Comment (1936) 34 MrcE. L. REv. 672.

14. See Blachly and OAtman, op. cit. supra note 6, at c. 7; Report of the Special Committee on Administrative Law (1934) 59 A. B. A. Rep. 539, 556 et seq.; list presented by Senator Byrnes, 82 Cong. REc. 53 (1937).

15. Rev. Stat. \$321 (1875), and amendatory statutes, 26 U. S. C. A. \$1691 (1934).

16. Act of August 24, 1935, 49 Stat. 750, 7 U. S. C. A. $\$ 601$ et seq. (1934), as amended by the Agricultural Marketing Agreement Act of 1937, Pun. L. No. 137, 75th Cong., 1st Sess. (June 3, 1937).

17. Act of May 20, 1926, 44 Stat. 568, 49 U. S. C. A. $\$ 171$ et seq. (Supp. 1937).

18. A few examples: the President is authorized to issue regulations under the Connally Act which prohibits the transportation of "contraband oil" (oil produced in excess of quotas allowed by state laws), Act of February 22, 1935, 49 STar. 30, 15 U. S. C.A. $\$ 715$ (Supp. 1937); he may proclaim changes in rates of duty under the Flexible Tariff Act, Act of June 17, 1930, 46 StAт. 696, 19 U. S. C. A. §1330 et seq. (1934); he may prescribe "such regulations as he may think fit" for carrying into effect acts relating to Indian affairs, REv. STAT. $\$ 465$ (1834), 25 U. S. C. A. §9 (1934); he may prescribe rules and regulations to carry out the provisions of the Neutrality Act, Public Resolution No. 27, 75th Cong., 1st Sess. (1936). See Hart, The Ordinance Making Powers of the President (1925).

19. Created by the Securities Exchange Act of 1934, 48 Stat. 881, 15 U. S. C. A. $\$ 78$ a et seq. (1934). Other regulatory commissions are: the Interstate Commerce Commission, note 3, supra; the Federal Trade Commission, note 4, supra; the Federal Communications Commission created by the Communications Act of 1934, 48 Stat. 
the other is the agency which is mainly administrative, but which has certain legislative powers, typified by the Social Security Board.9

3. Adjudicative pozers of executive departments. The adjudicative power is a frequent concomitant of the legislative power, particularly when the latter includes the power to issue permits or licenses. The officer having power to issue the license is also given power to revolse it. A typical example is the power of the Secretary of Agriculture to issue and revoke licenses to classify, grade, or veigh agricultural products. $^{21}$ Another typical adjudicative power is that of the Secretary of Labor with respect to the deportation of aliens. ${ }^{22}$

4. Adjudicative powers of independent agencies. Three types may be distinguished here: (a) the administrative agency with adjudicative powers, e.g., the Veterans' Administration ${ }^{23}$ (b) the regulatory agency with adjudicative powers, e.g., the Federal Communications Commission; $;^{24}$ and (c) the purely adjudicative agency, e.g., the National Labor Relations Board. ${ }^{25}$

5. Administrative courts. These are purely adjudicative agencies with jurisdiction to review the actions of other administrative agencies. The

1064, 47 U. S. C. A. \$1064 et seq. (Supp. 1937) ; the National Bituminous Cosl Commission, created by the Bituminous Coal Act of 1937, Pub. L. No. 48, 75th Cong., 1st Sess. (April 26, 1937) ; the Federal Power Commission, created by the Aict of June 23, 1930, 46 Star. 797, 16 U. S. C. A. \$791 et seg. (1934); the Federal Alcobol Administration created by the Federal Alcohol Administration Act, 49 Srar. 977 (1935), 27 U. S. C. A. § 201 et seq. (Supp. 1937).

20. Created by the Social Security Act, 49 SrAr. 620 (1935), 42 U. S. C. A. $\$ 301$ et seg. (Supp. 1937). Other independent agencies having legislative powers are: the Veterans' Administration created by the Act of July 3, 1930, 46 SrAr. 1016, 38 U.S. C. A. $\$ 11$ (1934), and Executive Order No. 5398 of July 21, 1930; the Farm Credit Administration created by Executive Order No. 6084 of March 27, 1933, confirmed by the Act of May 12, 1933, 48 Stat. 51, 12 U. S. C. A. $\$ 636$ ef seg. (1934); the Federal Home Loan Bank Board created by the Federal Home Loan Banl: Act, 47 Srar. 725 (1932), 12 U. S. C. A. $\$ 1421$ et seq. (1934); the Federal Reserve Board created by the Act of December 23, 1913, 38 Stat. 251, 12 U. S. C. A. $\$ 221$ af seq. (1934); the Federal Housing Administration created by the National Housing Act, 48 SrAt. 1246 (1934), 12 U.S.C.A. \$1071 et seq. (1934); the General Accounting Office, created by the Act of June 10, 1921, 42 Stat. 23, 31 U. S. C. A. $\$ 41$ et seq. (1934); the United States Maritime Commission, created by the Merchant Marine Act of 1936, 49 Srax. 1985, 46 U. S. C. A. $\$ 1101$ et seq. (Supp. 1937).

21. 42 Star. 1283 (1923) as amended by 46 Stat. 1464 (1931), 7 U. S. C. A. $\$ \S 252$, 253 (1934).

22. 39 Stat. 887 (1917), 8 U. S. C. A. $\$ 154$ et seq. (1934).

23. See note 20 , supra.

24. See note 19, supra.

25. Created by the National Labor Relations Act, 49 STגт. 449 (1935), 29 U. S.

C. A. § 151 et seq. (Supp. 1937). 
group comprises the Board of Tax Appeals. ${ }^{26}$ the Customs Court, ${ }^{27}$ the Court of Customs and Patent Appeals, ${ }^{28}$ and the Court of Claims, ${ }^{28}$

6. Anomalous agencies. A number of agencies cannot be fitted into these patterns. The Tariff Commission is a fact-finding body with certain adjudicative functions. ${ }^{30}$ The Grain Futures Commission is an adjudicative body consisting of three cabinet officers. ${ }^{31}$ The District Court of the District of Columbia has certain adjudicative functions of an administrative nature. ${ }^{32}$ Other examples can be found which cannot be fitted into any definite pattern. ${ }^{33}$

The legislative development of powers as here classified has never been marked by any consistent principle. ${ }^{34}$ If a newly created power bears a

26. Created by the Act of June 2, 1924, 43 Stat. 336, 26 U. S. C. A. $\$ 600$ et seq. (1934).

27. Created by $\S 518$ of the Tariff Act of 1922, 42 Srat. 972, as the Board of General Appraisers, now governed by $\S 518$ of the Tariff Act of 1930, 46 STAT. 737, 19 U. S. C. A. $\$ 1518$ (1934).

28. Created by the Act of August 5, 1909, 36 SrAT. 91, 105, 28 U. S. C. A. $\S 301$ et seq. (1934).

29. Created by the Act of February 24, 1855, 10 STAT. 612,28 U. S. C. A. $\S 241$ et seq. (1934).

30. Created by $\S 330$ et seq. of the Tariff Act of 1930, 46 Stat. 696, 19 U. S. C. A. $\$ 1330$ et seq. (1934). The commission is authorized to investigate unfair practices in import trade and to make findings for transmission to the President, who is authorized to exclude from entry articles concerned in such unfair methods.

31. The administration of the Grain Futures Act, 42 Stat. 998 (1922), 7 U. S. C. A. $\$ 1$ et seq. (1934), is entrusted to the Secretary of Agriculture, but the Grain Futures Commission, consisting of the Secretary of Agriculture, the Secretary of Commerce and the Attorney General, is authorized to suspend or revoke the designation of a board of trade as a "contract market." The first Federal Power Commission was composed of the Secretaries of War, Interior and Agriculture. Professor Frankfurtar found this to be "one of the chief sources of the Commission's failure." THE Punuc AND ITS GoverNMENT (1930) at 119.

32. Thus, this court has jurisdiction to review decisions of the Commissioner of Patents suspending or excluding patent attorneys or agents from practice. Rev. Stat. $\S 487$, as amended 42 STAт. 390 (1922), 35 U. S. C. A. $\$ 11$ (1934).

33. Note the National Mrunitions Control Board consisting of five cabinet officers established under the Neutrality Act, Public Resolution No. 27, 75th Cong., 1st Sess. (1936). Under the Connally Act regulating the interstate transportation of oil, the President is authorized to establish so-called "Tender Boards" which have power to grant or withhold certificates for shipment. 49 StAT. 31 (1935), 15 U. S. C. A. \$ 715(d) (Supp. 1937). The General Accounting office has been considered by some to be primarily adjudicative. by others to be sti generis. It would appear to be primarily an administrative agency with certain legislative and adjudicative powers.

37. Professor Cushman in his Problem of the Independent Renulatory Com-

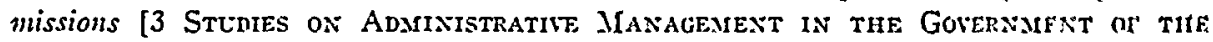
Uxited States (1937) 10] gives the following reasons for the establishment of inde. pendent regulatory agencies: (1) quasi-judicial functions may be handled more impartially by an independent agency; (2) fear of political pressure in the executive departments; (3) experts may be more willing to work in an independent agcncy; (4) 
resemblance to some existing power, Congress is likely to confer it on the agency already in existence; thus, the Secretary of Agriculture is given power to regulate futures trading in butter, eggs, and potatoes ${ }^{35}$ because he already regulates futures trading in grain, and similarly the Interstate Commerce Commission is given power to regulate motor transportation. ${ }^{36}$ But there is no definite rule. The Secretary of Commerce was empowered to regulate air transportation, ${ }^{37}$ although the matter could just as easily have been entrusted to the Interstate Commerce Commission. The National Labor Relations Act created a new agency, although very similar functions were already being exercised by the National Mediation Board under the Railway Labor Act. ${ }^{38}$ Curiously enough, the latter Board now has jurisdiction over labor relations in air transportation. ${ }^{38 .}$

Often a newly created power will resemble several different existing powers. You might assign the power to regulate electric utility companies either to the Federal Power Commission because electric power is involved, or to the Securities and Exchange Commission because securities are involved, or to the Federal Trade Commission because holding compamies are involved, or to the Federal Communications Commission because transmission of energy by wires is involved. Actually Congress adopted a Solomonic course and divided the baby between the first two

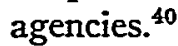

Sometimes Congress cannot quite make up its mind and puts an agency in an anomalous position. The National Bituminous Coal Commission is "in the Department of the Interior," although it is difficult to discover a perceptible difference between such a status and one of complete independence. ${ }^{41}$ The Federal Alcohol. Administration was first created

regional representation was desired in some agencies; $(5)$ no existing agency performing similar functions; (6) experimental character of some of the regulatory tasls; (7) belief that rule-making functions ought to be performed by a group rather than a single officer; (8) the prestige of the Interstate Commerce Commission.

35. Commodities Exchange Act, as amended June 15, 1936, 49 STAт. 1491, 7 U. S. C. A. $\$ 1$ et seq. (Supp. 1937).

36. MIotor Carrier Act, 49 Stat. 543 (1935), 49 U.S.C.A. $\$ 301$ et seq. (Supp. 1937).

37. Air Commerce Act. See note 17, sipra.

38. Act of Mlay 20, 1926, as amended, 44 Stat. 577, 45 U. S. C. A. $\S$ isl et seq. (Supp. 1937).

39. Act of April 10, 1936, 49 Stat. 1189, 45 U. S. C. A. \$181 el seq. (Supp. 1937).

40. Title I of the Act of August 26, 1935, 49 Stat. 803, 15 U. S. C. A. $\$ 79$ ef seq. (Supp. 1937) is entitled Control of Public Utilily Holding Companiss and is administered by the Securities and Exchange Commission; Part II, 49 Srar. 847, 16 U. S. C. A. $\$ 824$ et seq. (Supp. 1937) is entitled Regulation of Elcctric Utility Companies Engaged in Interstate Commerce and is administered by the Federal Power Commission.

41. Professor Cushman, op. cit. stipra note 34, at 7, states that this status means that the budget of the Commission and its "gcneral servicing" are cleared through 
"as a division of the Treasury Department," 42 and was later made an independent establishment. ${ }^{43}$ The Shipping Board began as an independent commission, ${ }^{44}$ then became a bureau in the Department of Commerce, ${ }^{45}$ and finally became independent again under the name of the Maritime Commission. ${ }^{46}$ The newly created United States Housing Authority was placed "in the Department of the Interior," largely because the present Secretary of the Interior had served as Administrator of the Public Works Administration and had, in his latter capacity, built up a staff of housing experts. ${ }^{47}$

The most significant legislative motive for the choice of the repository of a newly created power has been political. Agencies quickly develop definite characteristics of personnel, procedure, and policy. Consequently, it may make a good deal of difference whether you put control over foods and drugs in the hands of the Federal Trade Commission or the Secretary of Agriculture. If the Treasury or the Federal Reserve Board had been given the powers now exercised by the Securities and Exchange Commission, the present emphasis would most probably have been laid much more on control of the mechanism of credit rather than on protection of the investor. These political considerations will inevitably remain in the forefront of legislative consideration. Existing agencies have congenital characteristics which the most heroic efforts cannot change. Newly created agencies quickly develop their own. Nonetheless, other consider-

the Department of the Interior. He believes that because of this status this Commission makes "an interesting contribution to the study of administration." However that may be, there is some evidence that the status may be the result of accident. The original Bituminous Coal Conservation Bill introduced in 1935 [S.2481, 74th Cong., 1st Sess. (1935)] contained one title providing for the regulation of coal prices and labor relations and a second title providing for the creation of a bituminous coal reserve. The latter title was to be administered by the Secretary of the Interior, and it may well have been felt that more unified administration would be secured if the Commission which administered the first title were also connected with the Department of the Interior. Title II was stricken out in committee, but the words "in the Department of the Interior" were left in Title I, and the bill was passed in this form. These words were carried over into the new Bituminous Coal Act of 1937 after the invalidation of the first Act, perhaps because it was felt that the prior situation of the Commission should not be changed pending Congressional action on the President's message of January 12, 1937, which recommended that all independent agencies be placed "in" executive departments.

42. Act of August 29, 1935, 49 Stax. 977, 27 U. S. C. A. § 201 et seq. (Supp. 1937). This agency is the successor of the Federal Alcohol Control Administration created by Executive Order under the National Industrial Recovery Act.

43. Act of June 26, 1936, 49 Stat. 1964, 27 U. S. C. A. \$202(a) (Supp. 1937).

44. Act of September 7, 1916, 39 Star. 729, 46 U. S. C. A. $\$ 804$ (1934).

45. By Executive Order No. 6166 of June 10, 1933.

46. Merchant Marine Act, 1936. See note 20, supra.

47. United States Housing Act of 1937, Pub. L. No. 412, 75th Cong,, 1st Sess. (Sept. 1, 1937). 
ations, which must be taken into account, are susceptible of reduction ?o intelligible principles. These; it seems to me, are the questions on which we need some light:

1. Which functions are peculiarly adapted for exercise by an executive department, by a regulatory commission, by an adjudicative cornmission, or by an administrative court ? $^{48}$

2. Is it possible to make a reasonable distinction batween legislative and adjudicative functions? If so, to what extent should these iunctions be segregated? ? $^{49}$ A number of writers have assunied that the two should always be segregated. It may be doubted whether close examination would justify this extreme position. ${ }^{50}$

3. To what extent may the adjudicative functions with respect to different subjects be consolidated in one agency? Would it be possible to consolidate certain adjudicative functions of a similar character, e.g., the power to revoke licenses and permits of whatever nature, or to consolidate all adjudicative functions with respect to certain types of subject, e.g., with regard to unfair competition or securities issues?

The problem of the choice of agency raises the question of the extent to which legislative and adjudicative agencies should be independent of the executive. Many persons assume that only an independent agency like the Interstate Commerce Commission can be trusted to be impartial. Investigation will probably show that the adjudicative functions of the executive departments have been as free from political interference as those of the independent agencies. ${ }^{51}$ A great deal has also been said of

48. I am not suggesting that any criteria can be erolved which will autcmatioally tell us where to assign the various functions of administration. It must be recognized that political reasons will always remain in the forefront. Cf. Hsnras, Puterc Anurnistration aNd the Public Ixterest (1936) 347. Reasonable criteria would, however, help greatly in guiding political judgment.

49. See, e.g., Report of the Special Committec on Administrative Low (1934) 59 A. B. A. Rsp. 539, 544-551. Cusmasan, op. sit. sipro note 34, at 23 at seg. suggests that all zegulatory agencies be divided into two sections, one "administrative" to be incorporated. into an executive department, and the other "judicial" (handling both judicial and quasi-judicial matters) to be "in" the department for purposes of "administrative housekeeping" but otherwise completely independent. BLACBLY Arid OATsari, op. cit. supra note 6, at 261 et seq. vould transfer adjudieative functions to a system of administrative courts.

50. The Committee on Ministers' Powers, while recommending tiat "judicial" functions should normally be entrusted to the ordinary courts of law, took the view "that quasi-judicial decisions fall properly within the province of executive Ministers, who are responsible for policy and should control, direct, and administer it, and that such decisions should not ordinarily be assigned to any tribunal other than the Minister." REPORT, op. cit. supra note 2 , at 115 .

51. It has never been suggested that the rate orders issued by the Secretary of Agriculture under the Packers and Stockyards Act have been infuenced by folitical considerations, and those of his orders which have been considered on the merits by 
recent years with regard to the tenure of the members of independent commissions. $^{52}$ It has been suggested that they should be appointed either for very long terms or for life, as are the Federal judges. ${ }^{53}$ Yet it must not be forgotten that these commissions are policy forming bodies as well as adjudicative bodies. Should they be as completely independent of the executive as are the courts? Executive control is an unmitigated evil when it reaches down to individual cases and warps the judgment of the administrators; it may be beneficent, however, when it guides the general policy along the lines indicated by the electorate and Congress. ${ }^{54}$

Such problems are of too delicate a nature to be solved by easy catch words. Facts are needed, a great many more facts than we now have. A recent suggestion that the budgets of independent commissions be handled by executive departments ${ }^{55}$ has evoked a storm of protest against this supposed executive domination. The protestants have failed to note that the budgeting and general servicing of the Federal judiciary is handled by the Department of Justice. ${ }^{56}$ Yet no one lias intimated that this control has resulted in executive domination of the courts. ${ }^{57}$ Perhaps the situation would be different with respect to administrative bodies. Many of us feel that it would, but it is to be doubted whether any of us have sufficient data to form a considered judgment on the issue.

the Supreme Court have been upheld in all respects. See St. Joseph Stock Yards v. United States, 298 U. S. 38 (1936); Acker v. United States, 298 U. S. 426 (1936).

52. This problem seemed important enough to the American Bar Association to form the subject of the Ross Bequest Essay Contest for 1937, under the title, The Administration of Justice as Affected by Insecurity of Tenure of Judicial and Administrative Officers. The prize winning essay reached the conclusion that "all of the more important federal administrative officers exercising judicial functions" should hold office durine good behavior. (1937) 23 A. B. A. J. 930, at 936.

53. The Logan Bill for a United States Administrative Court provided for life tenure for the judges. See note 8, supra. For a trenchant criticism of permanency of tenure, see Friedrich \& Cole, Responsible Bureaucracy: A Study of the Swiss Civil Service (1932) 16.

54. A discussion of this problem will be found in Cusmasan, op. cit. supra note 34, at 13-17. See Fuchs, Concepts and Policies in Anglo-American Administrative Law Theory (1938) 47 YAL̇e L. J. 538, 573 ff.

55. Id., at 23 .

56. The Act of June $28,1902,32$ Stat. 476,31 U. S. C. A. $\S 663$ (1934) provides : "Money appropriated for supplies for the United States courts and judicial officers, shall be expended in payment for such supplies only as shall be purchased, in the discretion of the Attorney General, for delivery at the Department of Justice for distribution." The salaries of judges are paid through the Department of Justice and the United States Marshals. Act of August 1, 1914, 38 STAT. 653, 28 U. S. C. A. $\$ 505$ (1934); Act of July 31, 1894, 28 Stat. 210, 5 U. S. C. A. $\$ 321$ (1934). The appropriations for the judiciary are included annually in the appropriations for the Department of Justice.

57. Judge Denman has recently criticized the present system because of its inefficiency. Hearings on Reorganization of the Federal Judiciary, 75th Cong., 1st Sess. (1937) 481. 
After the choice of agency has been made, numerous organizational problems remain. The existing agencies show wide diversity of organization. Some agencies are completely centralized in WVashington, as, e.g., the Communications Commission. Other agencies have established regional offices which reproduce in miniature the central organization. Thus, the National Labor Relations Board has a considerable number of such regional offices, each headed by a Regional Director assisted by attorneys and so-called field examiners. Other agencies operate through itinerant trial examiners, who sit wherever it is found most convenient to hold the hearing. The Federal Trade Commission follows this practice. The motor carrier division of the Interstate Commerce Commission operates in part through so-called joint boards composed of members designated by state agencies assisted by a Commission examiner. ${ }^{58}$

In a collegial commission the question is always present whether the commission should operate through individual members, through small divisions, or en banc. The statutory provisions vary widely. The Interstate Commerce Commission and the Cummunications Commission are authorized to act through divisions of not less than three members, or through boards of employees, or through individual commissioners. ${ }^{50}$ The action of a division cannot be reviewed, but the action of a board or individual commissioner is subject to review either by the Commission as a whole or by a division. The Bituminous Coal Commission is authorized to establish divisions, each of which may exercise all the powers of the Commission, but a person in interest is entitled to secure a review by the Commission as a whole of any finding made by a division. ${ }^{c \theta}$ The Board of Tax Appeals is authorized to act through divisions of one or more members. The "reports" of divisions may be reviewed by the Board at the direction of the Chairman, but a taxpayer may not request such a review as of right. ${ }^{81}$ The statutes creating the Federal Trade Commission, the Securities and Exchange Commission, the Federal Alcohol Administration and the National Labor Relations Board are silent on this point.

In the executive departments, the legislative or adjudicative functions are ordinarily conferred on the head of the department, although occasionally they may be expressly conferred on a subordinate officer, e.g., the Commissioner of Internal Revenue, who is an officer of the Treasury

58. See Kauper, Utilization of State Commissioners in the Administranon of the Federal Motor Carrier Act (1935) 34 MfICr. L. Rev. 37.

59. $\S 17$ of the Interstate Commerce Act, 24 SrAr. 385 (1887), 49 U. S. C. $\S 17$ (1934); Sec. 5 of the Communications Act, 48 Srar. 1058 (1934), 47 U. S. C. A. $\S 155$ (1934).

60. $\$ 2$ of the Bituminous Coal Act, Pub. L. No. 48, 75th Cong., 1st Sess. (April $26,1937)$.

61. $\S 601$ of the Revenue Act of 1928, 45 Stat. 871, 26 U.S.C.A. $\S \S 603,617,618$ (1934). 
Department. The Morgan case, discussed hereafter, ${ }^{62}$ in which the Supreme Court held that the officer who makes an adjudicative decision must personally consider evidence and argument, may lead to considerable changes in the existing distribution of these functions within the executive departments.

A number of the departments and agencies contain special review boards; very rarely are these provided by statute, e.g., the Processing Tax Board bf Review, which reviews determinations of the Commissioner of Internal Revenue with respect to refunds of processing taxes. ${ }^{63}$ Other such boards have been set up in the absence of statute and are purely advisory, e.g., the Board of Review in the Department of Labor, which reviews determinations of the Boards of Inquiry in the Immigration Service. ${ }^{64}$

The problems of internal organization, while of less significance from the standpoint of general policy than problems of the choice of agency, must stand in the forefront of any consideration of improvement of efficiency. Generally speaking, such problems must be solved according to the requirements of the specific agency. Unfortunately, the framework of the organization is ordinarily established at the beginning of the agency's life when no experience is available. Disinterested examination after the agency has been in operation a number of years might well result in the change of organization.

If a commission may divide itself into a number of divisions, it will be able to work much faster. However, private persons are unwilling to gamble on the capabilities of a particular member or division, and inevitably the demand arises either for a Board of Review or for review en banc. These reviewing boards have sprung up rather haphazardly. A committee of the American Bar Association has recently recommended that all heads of departments be required to set up review boards to which any person "aggrieved by a decision, act, or failure to act" by any officer or employee of the department may resort. ${ }^{65}$ Would this extend to the refusal of an officer of the Department of State to recommend to the Secretary that a reciprocal trade agreement be negotiated, or to the rejection of a bid by a procurement officer? Would it not entail so much expense and delay, so many possibilities of confusion that it would discredit the whole idea of intra-departmental review? It would be of greatest

62. Morgan v. United States, 298 U. S. 468 (1936); see pp. 662-4, infra.

63. $\S 906$ of the Revenue Act of 1936,49 STAr. 1748,7 U. S. C. A. $\S 648$ (Supp. 1937).

64. Boards of special inquiry are authorized under $\$ 17$ of the Act of February 5, 1917,39 Stat. 887,8 U. S. C. A. $\$ 153$ (1934). For a discussion of the Board of Review, see Rep. No. 5, National Commssion on Law Observance and EnrorceMent, Deportatton Laws (1931) 157 et seg.

65 . See report cited note 10 , supra, at 225-226. 
value to know to what extent review boards are necessary. I find it hard to believe that every "decision, act or failure to act" should be subject to this sort of review. Here, as in many other places, inquiry and experiment should precede general innovation.

\section{Procedural Problears}

Few fields of law offer so much opportunity for valuable research and instructive suggestion as the field of administrative procedure. Two factors have made this study more propitious now than ever before. In the first place, the Federal Register now publishes the rules of procedure of the rarious agencies. In the past these were, in many cases, practically unarailable. In the second place, the Supreme Court has recently handed down a number of decisions of primary importance on procedural questions, and the beginnings of a body of case law are now before us.

There are, of course, innumeratle problems of procedure to which attention can be directed. I shall attempt here to sketch out only the few which to me seem most pressing. ${ }^{\text {co }}$

Hearings-when Required. We can start with the administrative hearing. When should it be required? It is fairly well settled that when the exercise of an adjudicative funzion is in question, due process of law requires a hearing, and one which is as extensive as may be required by the issues to be adjudicated. ${ }^{67}$ The problem arises in connection with legislative functions. The power to issue regulations is a legislative power, and no one has ever supposed that an act of the legislature is rendered invalid by failure to hold hearings. On the other hand, legislatures usually do hold hearings on inportant measures.

Until recent years, most administrative agencies issued regulations without notice and hearing, and most agencies still continue to do so. ${ }^{\text {cS }}$ However. the N.R.A., with its slogan of "partnership of government and business." adopted the pracice of holding hearings on the codes of

66. One of the important problems not discusscd is that of the organization and procedure for issuing administrative rogulations (with the exception of the question of hearing). This omission is due to the fact that the problem has recently been given exhaustive treatment under the auspice of the President's Committee on Administrative

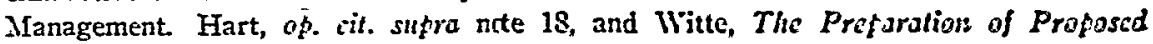

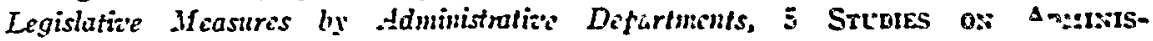

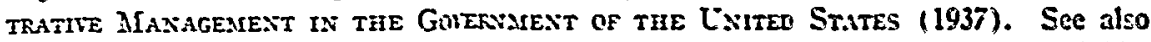

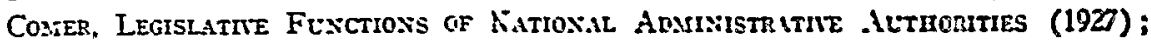

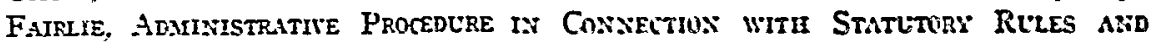

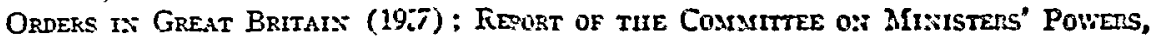
op. cit. saipra note 2 , at sec. II.

67. Infcrstate Com. Comn. r. Louistille \& Nashville R.R., 227 U. S. 8 \&, 91 (1913); Soutliem Ey. v. Virginia, 29) i. S. 190 (1933).

68. An outstanding exception has been the Interstate Commerce Commission in which leg"slative procedure is closeiy assimilated to adjudicatire procedure. 
fair competition. The practice was extended to other agencies after the Supreme Court's decision in the Panama Refining case, ${ }^{60}$ which struck terror into the hearts of many administrators. When the Agricultural Adjustment Act was amended in 1935, the Secretary of Agriculture was required to give notice, hold hearings, and make findings as a prerequisite to the issuance of "orders" regulating the handling of conmodities. ${ }^{70}$ The recent Bituminous Coal Act provides that "no rule or regulation which has the force and effect of law, shall be made or prescribed by the Commission, unless it has given reasonable public notice of a hearing, and unless it has afforded to interested parties an opportunity to be heard, and unless it has made findings of fact." "i1

It is not easy to determine just what the nature of these hearings should be. Regulations usually affect great numbers of persons, and if several hundreds attend a hearing, it is apt to become rather unwieldy. Often, it would be a physical impossibility to permit protestants to present evidence with as great freedom as in a court. and if cross-examination is to be freely allowed, the hearing might continue indefinitely. Under these circumstances, the hearing must assume the characteristics of a hearing before a legislative committee instead of one before a court.

What then is its utility? For one thing it may be a convenient way of getting information; for another, it is useful to have objections to proposed provisions thrashed out in pubic discussion. ${ }^{72}$ But since the hearing must be strictly controlled by the administrative officer in order to make it at all practicable, it may not be a particularly useful check on the reasonableness of administrative action. The most a statute can do is to provide that the regulations must be supported by substantial evidence. In practice this safeguard is rather illusory. The administrative

69. Panama Refining Co. v. Ryan, 293 U. $\subseteq 388$ (1935).

70. $\$ 8(c)$ of the Agricultural Adjustment Act as amended, Pub. L. No. 137, 75th Cong., 1st Sess. (June 3, 1937); 7 U. S. C. A. \$608(c) (Supp. 1937).

71. \$2(a) of the Bituminous Coal Act, supre note 60. There has been other recent legislation in which similar provision has been made. $\$ 5(f)$ of the Federal Alcolol Administration Act, 49 Stat. 984 (1035), 27 U S. C. A. $\$ 205$ (Supp. 1937); $\$ 4$ of the Trade Agreements Act, 48 SraT. 945 (1934), 19 U. S. C. A. $\$ 1354$ (1934). Courts are sometimes exceedingly strict in their interpletation of such provisions. Sce, idg., Carl Zeiss, Inc. v. United States, 76 F. (2d) 412 (C. C. P. A. 1935).

72. "Formal hearings on proposed regulations have special advantages which closely parallel those of congressional debates and committee hearings. They give publicity to the rule-making process. They give those affected a chance to have their say in a public forum. They give administrators a means of seeng that all parties in-interest are heard, by giving as much time to consumer as to trade spokesmen. and by carrying the hearings into different localities in order to give a break to the little fellow. They also may secure facts and points of view not readily secures by any other means. They build up a public record. They bring to public attentior the phenomenon of piessure politics, and this may have some educational value for public opinion. In short, they keep rule-making from being done in a corner." HART, op. rit. supra note 18 , at 30 . 
agency is often able to put some evidence in the record as a justification, and if cross-examination of the agency's witnesses is excluded, it may be almost impossible to break down their evidence.

If we assume that such hearings do have utility, when should use be made of them? A committee of the American Bar Association desires a universal requirement. ${ }^{73}$ Others might say that if the Treasury were to hold hearings on all of the manifold regulations which it issues, its officers would probably have little time to do anything else. If the requirement is not to be universal, what should be the line of demarcation between the regulations which require hearings and those which do not? It might be possible to classify regulations on the basis of their substance or on the basis of the conditions on which they are issued. Regulations which supply the details of a course of conduct prescribed by the legislature, e.g., the hours at which drawbridges should be opened and the signals which should be given, or how many sheep may be permitted to graze on government land, or how a particular deduction should be taken by a taxpayer, apparently differ from those which crystallize into concrete form a general legislative purpose, e.g., which fix the minimum price for coal or milk, or fix transportation rates. Hearings might be required for the latter group and not for the former. Some regulations must be issued as a matter of course, e.g., tax regulations, while others lie largely within the discretion of the agency, e.g., when a "milk order" should be issued by the Secretary of Agriculture. Perhaps we should require a hearing for the latter kind in order to provide some check on the exercise of discretion. But it is far easier to outline broad general differences between different types of regulations than to determine whether a particular regulation is of one type or the other. It may well be that the difficulties of classification are insuperable and that the only solution is to make the holding of hearings discretionary with the agency.

73. See report cited note 10 , supro at $224-225$. The committee recommends that all agencies be required to issue regula tions "to implement every statute afiecting persons or property, required to be administered or enforced by" such agency, these regulations to be subject to review by the Court of Claims on petition to be filed in accordance with rules of the Court. The advantages of implementing statules by regulations are great, but it is hard to see how agencies can be forced to issue them as a practical matter. Those who dislike advisory opi nions in constitutional cases will find the reviev procedure most unsatisfactory, partic ularly since it is not possible to provide for any appeal to the judicial courts from suc h dacisions of the Court of Claims. A step towards requiring implementation by regulati ons was taken in Heitmeyer v. Federal Communieations Commission (App. D. C., D cc. 27, 1937). An order denying an application for a radio station permit on the gro und of alleged lack of financial responsibility was sat aside. The court said: "We are referred to no rule or regulation of the Commission suggesting such a rigid standard. On such an important question we thinl: the public is entitled to have the statute implemented by a regulation setting out clearly and concisely just what the Commiss ion regards as a minimum standard of financial ability." 
Hearings-What are the Requisites? A recent Supreme Court decision, dealing with the nature of an adjudicative hearing, has raised a new crop of problems with respect to administrative procedure. Morgan v. United States ${ }^{74}$ involved a proceeding to enjoin the enforcement of an order of the Secretary of Agriculture fixing maximum rates to be charged by market agencies at the Kansas City Stock Yards. An elaborate hearing had been reld before an examiner of the Department of Agriculture. Subsequentl, there was an oral argument on the evidence held before the Assistant Secretary of Agriculture, who was then the Acting Secretary. The order $*$ as then issued over the signature of the Secretary of Agriculture himselt. The plaintiffs alleged in their bill of complaint that the Secretary had not , ersonally heard or read any of the evidence or oral arguments and had not read or considered any of the briefs submitted. The lower court, on motion of the Government, struck out these allegations. The Supreme Court held this to be error. It said that although the Secretary could, so far as permitted by statute, delegate the duty of taking down the evidence, or even the duty of making a decision, he could not himself make a decision without personally considering and appraising the evidence. "The 'hearing' is the hearing of evidence and argument. If the one who determines the facts which underlie the order has not considered evidence or argument, it is manifest that the hearing has not been given . . The one who decides must hear." 75

This decision seems so eminently reasonable on its face that some explanation. is needed before its revolutionary character can be appreciated. The Secretary of Agriculture administers forty-two regulatory statutes. In addition, he administers a host of non-regulatory statutes, some of them, like the Soil Conservation and Domestic Allotment Act, of high national importance. Finally, he is a major political officer and takes part in the formulation of national policy as a member of the Cabinet. If he were to give to every order which he signs the consideration which the Morgan case requires, he would probably have to devote all his time to the conduct of matters which must be considered petty from a national viewpoint.

What is to be done about this situation? Should the function of making orders be delegated to subordinate officials? There is considerable psychological value in having the signature of the Secretary himself on the order. It would carry less weight if signed by an unknown subordinate. There is also the danger of a relaxation of responsibility in case of a complete delegation. Even if the Secretary does not give full consideration to the evidence, he at least brings his attention to bear upon the

74. 298 U. S. 468 (1936).

75. Id., at 481 . 
problem, and does review the order, however sketchily, before signing it.

Should we put all these functions of the Secretary of Agriculture and of other executive officers "in commission?" This might preserve the advantages which would be lost by delegation to subordinate officers, but would we be willing to face a great increase in the number of independent commissions? It is possible that the Morgan rule does not apply to procedure before a commission. The Supreme Court distinguished the Arlidge case, ${ }^{76}$ in which the House of Lords laid down a diametrically opposite rule, in part on the ground that it related "to a different sort of administrative action."77 The only ascertainable difference is that the Arlidge case involved a proceeding before a board. Is there any reason why a board or commission should be able to decide without consideration of the evidence, if an executive officer may not?

Aside from the necessity for substantial reorganization of the procedure of many agencies which the Morgant case implies, there is also suggested the possibility that administrative orders may be subject to attack on the ground of insufficient consideration of the evidence by the deciding officer. We may even witness the incredible spectacle of long trials in which administrative officers are questioned at length on the amount of time which they spent in reading the record and what their mental attitudes were. This actually happened in the Morgan case. When the case went back for trial to the lower court, the plaintiffs submitted over a hundred interrogatories to the Secretary, and elaborate depositions were taken. The Secretary was asked how much time he had devoted to the testimony of each witness and to each exhibit, what weight he had accorded to such testimony, what pages of the briefs he had read, what theories of rate making he had considered and rejected, etc. ${ }^{78}$ If this sort of thing is to be permitted, administrative adjudication will become an ineffectual farce.

Much of the difficulty created by this decision would be obviated by limiting it in two respects. First, the rule might be applied only in a situation like the Morgan case, i.e., where the person who issues the order did not himself hear the oral argument. This would restrict greatly the number of cases in which orders would be attacked on this ground.

76. Loca! Government Board v. Arlidge, [1915] A. C. 120, rev'g, King v. Losal Government Baard [1914] 1 K. B. 160.

77. 298 U. S. at 482 (1936).

78. See Morgan r. United States, (U.S.Dist. Ct., W. D. Mfo.) Equity No. 2328 (1937), in which it was found on the basis of this testimony that the Secretary had complied with his duty as to the consideration of evidence and argument. The court construed the Supreme Court's decision as follows. "The Supreme Court hos not said that it vias the duty oi the Secretary of Agriculiure to teas or read all the evidence and, in addition thereto, to hear the oral argumeats and to read and consider briefs. If the Supreme Court hat said that it would have meant that the Fathers and Stccisyards Act cannot be aciministered." 
Second, the duty resting on the deciding officer might be satisfied, if he had considered the argument only and had not personally perused the evidence. No one has dared suggest that litigants may impeach the decision of judges of intermediate appellate courts on the ground that they had not read the record made before a lower court. No lawyer is naive enough to believe that judges actually read through the records in the cases before them. Why must the Secretary of Agriculture be more diligent than the judges? ${ }^{79}$

Precisely what the Morgan case means to administrative procedure must await a close examination of existing practice in all the agencies. ${ }^{80}$ It cannot be doubted that considerable changes will have to be made if the decision continues to stand. What these changes should be and how they can best be made consistent with the necessities of efficiency and the utterances of the Supreme Court can only be answered after intensive study.

Hearings-Who may participate? Administrative adjudications often impinge on interests lying beyond the range of the specific proceeding. When the Secretary of the Interior grants a grazing permit to one grazer, other grazers may be affected. When the Federal Trade Commission charges that a manufacturer is giving discriminatory discounts to certain wholesalers in violation of the Robinson-Patman Act, the wholesalers are intensely interested in the proceeding, and the customers of these wholesalers are almost as much concerned. The extent to which such indirectly affected interests should be allowed to participate in administrative proceedings is still undetermined. Most agencies provide in their rules of procedure for intervention by "interested parties." The phrase is so vague that no person can tell in advance whether or not he comes within its description. Administrators profess to fear the possibility of having proceedings overwhelmed by intervenors and tend to cut down the scope of "interest" whenever possible. Thus, the Federal Communications Commission, while providing in its rules for intervention by any person having a "substantial interest," refuses to permit one radio

79. "Let it be frankly stated now that the judges of this court, whose duty it was to consider the case de novo (since it involved constitutional issues), did not read all this testimony. We think, moreover, that it may be predicted with some assurance that all this testimony will not be read by the justices of the Supreme Court, when, as they must, they consider the cases on the merits." Ibid.

80. The Tariff Act of 1930 authorizes the Tariff Commission to investigate charges of unfair practices in import trade and to make findings for transmission to the President. The latter is authorized to exclude from entry articles concerned in such unfair practices. 46 Stat. 704, 19 U. S. C. A. $\$ 1338$ (1934). Does the Morgan case mean that such action by the President is invalid unless he personally considers the evidence and argument on the basis of which the Commission made its findings? A possible answer is that the President's act is exectitive in character and might have been atuthorized by Congress without the necessity of a hearing. 
station to participate in a proceeding brought by another station for modification of its license even though both stations are direct competitors in the same area. ${ }^{81}$

Even where the privilege of intervention is liberally allowed, it may not be effective if interested persons are not given notice of the proceedings. Yet, it would frequently impose an intolerable burden on an agency to require it to determine all the persons who might have an interest and to serve notice upon them. The National Railroad Adjustment Board has experienced the difficulties of this problem. This agency has jurisdiction over disputes between the carriers and their employees over the interpretation of contracts. ${ }^{82}$ Ordinarily a dispute arises between the carrier and a labor union representing the employees, and the Board has followed the policy of giving notice only to the carrier and the union. But the effect of an award against the carrier will be to deprive some employee or other of the advantage accorded to him by the carrier. The courts have held that such an aggrieved employee is entitled to notice and an opportunity to defend his rights, although the dispute is strictly between the carrier and the union as representative of the employees alleged to have been discriminated against. ${ }^{83}$

Such instances of judicial determination of the scope of an administrative hearing are rare. The problem has been handled by administrative agencies in haphazard fashion, and no attempt has been made at the development of consistent rules for intervention. Much could be accomplished by better definition of the term "interested parties," and this requires a study of the extent to which particular administrative proceedings affect outside persons.

Findings. When another person takes some action affecting our interests we naturally desire to know the reasons which motivated him: Courts have been azcustomed to satisfying this desire by writing opinions setting forth the grounds for their action. We all know that often they are content to let curiosity go unsatisfied and to refrain from writing opinions. The Supreme Court has never said that the Constitution requires that opinions be written, and it disposes of hundreds of cases every year with the simple phrase, "petition for writ of certiorari denied." It is only in recent years that it has required the Federal district courts to make findings of fact and conclusions of law. While the Crnstitution is thus lenient with respect to the courts, it is much harder on adminis-

81. See Sykes v. Wren Co., 78 F. (2d) 729 (App. D. C., 1935), ecrl. denicd, 296 U.S. 624 (1935); (1936) 45 YALE L. J. 934.

82. This Board is discussed by Garrison, The Notional Ruilroad Adjustment Beard: A Unique Administrative Agency (1937) 46 Y ALE L. J. 567.

83. Nord v. Griffin, 86 F. (2d) 481 (C. C. A. 7th, 1936); Estes v. Union Terminal Co., 89 F. (2d) 768 (C. C. A. 5th, 1937).

84. By Sec. $70^{1 / 2}$ of the Federal Equity Rules. 
trative agencies. When the latter act in an adjudicative capacity, they must make findings or else their action becomes void. irrespective of whether or not the statute requires the making of findings. ${ }^{{ }^{5}}$ Two rcasons are given for the rule. If an administrative officer could act without giving a reason, he might act for a reason outside his authority, and this would amount to an unfettered delegation of power. Further, since his action is subject to judicial review, the reviewing court would have no basis for review unless it knew why he took the action. Neither reason is particularly impressive. Whether or not an act is within the officer's delegated powers can always be seen from the face of his act. Even if he gives proper reasons for acting as he did, he may have had hidden motives which no court can probe. It is undeniably helpful to the reviewing court to have the reasons set forth, but how can this be a constitutional requirement when courts of first instance are free to act without findings?

It would profit us little to try to find a rational constitutional basis for the requirement. It should suffice that the practical basis is sound enough. The requirement is an excellent one. The advantages of carefully drawn findings are immense. They induce a sense of responsibility on the part of the administrative officer; their formulation aids immeasurably in the formulation of the decision; they limit the isstes to be decided on review and save the time of litigants and the courts. All these advantages flow from findings carefully drawn; if they are merely perfunctory they are completely useless. And it is in this category that a great proportion of the findings currently made by administrative agencies must be put. Almost fifteen years ago Henderson in his The Federal Trade Commission wrote a brilliant exposition of the problem. ${ }^{80}$ It is sad to contemplate how little his analysis and recommendations have affected current practise. The low water mark was reached in the NRA where (after the Panama Refining case had indicated that findings were necessary) every code began with a parroting of the preamble to the statute without regard to whether the code dealt with cnal or candlewick: bedspreads. I doubt whether any agency can now be found with so little sense of discrimination, but too many are still content to paraphrase the language of the statute rather than to give a clear account of the facts which led to the particular decision. There are, of course, salient exceptions, among which the National Labor Relations Board is particularly to be noticed. ${ }^{87}$

85. IVichita Railroad \& Light Co. v. Public Utilities Comm., 260 U. S. 48 (1922); Mahler v. Eby, 264 U.S. 32, 44 (1924). Cf. Heitmeyer v. Federal Communitations Commission, App. D. C., Dec. 27, 1937.

86. C. 3 (1924).

87. Note the graphic nature of the findings in the June's \& Langhlin case winch arc summarized in National Labor Relations Board v. Jones \& Laughlin Steel Corp., 301 U. S. I (1937). 
Here is a fertile field for scholars. Henderson has given the cue. What we need now is a study of the practise of other agencies with respect to findings of fact and detailed recommendations as to how it should be improved.

If the Supreme Court had contented itself with laying down the requirement for findings in adjudicative action, there would have been little cause for complaint on the part of administrative officers. However, in the last few years the Court has handed down a number of decisions with regard to findings as a prerequisite to legislative action. It began with the Panama Refining case. ${ }^{88}$ Section 9c of the Recovery Act authorized the President to prohibit the interstate transportation of oil produced or withdrawn from storage in excess of amounts permitted by State law. The statute required no findings, and the President made none. The Court held the statute invalid as an unconstitutional delegation of legislative power, and then held the President's order invalid because it was made without findings. The authority given to the President was purely legislative in nature. It was the same sort of power that had been exercised by executive departments and independent agencies for many decades. If findings were necessary here, were they not necessary in all cases of legislative action? Did this mean that the immense mass of regulations, those governing taxes, navigation, transportation, public lands, all the myriad activities within Federal control, were invalid because they have been issued without findings?

The Court had not made matters any easier by handing down on the same day an even more puzzling decision in United States $v$. Baltinore and Ohio R.R. ${ }^{89}$ The Boiler Inspection Act empowers the Interstate Commerce Commission to make regulations with respect to locomotives and their appurtenances which cause "unnecessary peril to life and limb." After an extensive hearing, the Commission had ordered the railroads to equip all locomotives above a certain size with power-operated reverse gears. The Court set the order aside because the Commission had failed to make a specific finding as to whether "the use of any or all types of steam locomotives 'equipped with hand reverse gear as compared with power reverse gear causes unnecessary peril to life or limb." "co The statute requires the Commission to make a report stating its "conclusions" together with its "decision." The Commission had rendered an elaborate report in which it had discussed the relative advantages and disadvantages of the two types of gears. But this was held not to be enough. The Court admitted that "formal and precise findings are not required" under the

88. 293 U. S. 388 (1935).

89. Id., at 454 .

90. Id, at 464 . 
Act, ${ }^{91}$ but held that this did not "remove the necessity of making, where orders are subjest to judicial review, quasi-jurisdictional findings essential to their constitutional or statutory validity." 02

The action of the Commission was of a legislative character. ${ }^{03}$ Does it follow that wherever regulations are issued "quasi-jurisdictional" findings must be made? It is said that the rule applies only "where orders are subject to judicial review." This particular regulation could under the statute be directly attacked by a proceeding to review. Most regulations can be attacked only collaterally in a proceeding either to enforce or to penalize a violation. But they also are subject to judicial review in this collateral proceeding. Certainly, no reasonable distinction can be made between a regulation which may be reviewed directly and one which may be reviewed only in a collateral proceeding. What precisely is the utility of a "quasi-jurisdictional" finding? If a commission is authorized to issue regulations "in the public interest," it would seem to be enough for it to say, "We find that it is in the public interest to issue these regulations." More cannot be required unless the Court is willing to force the holding of hearings and the making up of voluminous records.

While these two cases are puzzling enough, a third case has added further elements of confusion. In Pacific States Box \& Basket Co. $v$. White ${ }^{94}$ a regulation of a state department of agriculture was challenged on the ground that no findings had been made. The Court said:

"It is contended that the order is void because the administrative body made no special findings of fact. But the statute did not require special findings; doubtless because the regulation authorized was general legislation, not an administrative order in the nature of a judgment directed against an individual concern." 95

Does this decision overrule the Panama and Baltimore and Ohio cases? Presumably they still stand, but in a twilight zone of doubt.

There are plenty of problems waiting for investigation: and solution. Should findings be required as prerequisites to regulations? Can a reasonable classification be made between those which should be made on findings and those which should not? Is there any utility in a "quasijurisdictional" finding? If there is, which would be the most useful and

91. The original Interstate Commerce Act had required findings of fact, but the requirement was stricken out by $\S 3$ of the Act of June 29, 1906, 34 Srar. 589, 49 U. S. C. A. $\S 14$ (1934).

92. 293 U. S. at 465 (1935).

93. In form the proceeding was adjudicative, being directed against all the railroads as named respondents and being subject to direct judicial review. In substance it was clearly legislative, directing the railroads to install a specific type of apparatus on their equipment.

94. 296 U. S. 176 (1935).

95. Id., at 186 . 
practicable form? Where there is no hearing or record, should the findings set forth facts based on information found in the files of the agency ? $^{36}$ If formal findings are not possible, would it be useful to accompany regulations with an explanatory report giving the reasons for their issuance?

Presentation of Issues. The opinion in the Morgan case, ${ }^{07}$ heretofore discussed, brought to the fore the important problem of the form in which issues are to be presented for decision by the administrative officer or commission. The plaintiffs alleged that at the conclusion of the taking of testimony before an examiner a request was made that the examiner prepare a tentative report, which should be subject to oral argument and exceptions, but that the request was denied. The Supreme Court held that the particular type of procedure suggested was not essential to the validity of the hearing.

The procedure for which the plaintiffs had asked is the one followed by the Interstate Commerce Commission, the Securities and Exchange Commission, the National Labor Relations Board; and a number of other agencies. $^{98}$ The procedure is briefly as follows: After the conclusion of the hearing the trial examiner prepares a report which contains his findings of fact. Some agencies provide that he may in his discretion request proposed findings of fact from the parties, but there is no argument on these proposed findings before the trial examiner as is the case in trials before a court. The examiner's report is served on the parties who are then given an opportunity to file exceptions to the findings of the examiner or his failure to make findings or to the admission or exclusion of evidence. The parties are also permitted to file briefs in support of their contentions. On request of any party, oral argument is then had before the Commission, which subsequently issues an order containing its own findings.

The advantages of this procedure are obvious. The time of the commission is conserved since the issues are crystallized in the examiner's report, and the attorneys are enabled to address themselves to the specific points raised by the exceptions. The report apprises the parties of the nature of the case which can be made out for or against them, and may shape their arguments accordingly. The examiner's findings epitomize the record, often voluminous and stuffed with extraneous material, and

96. In United States v. Abilene \& Southern Ry., 265 U. S. 274 (1924), a finding by the Interstate Commerce Commission, based on reports which were found in its files but were not intraduced in evidence, was held void. Should not a different rule apply in the case of legislative findings where no hearing is necessary?

97. See p. 662, supra.

98. Since the Morgan case the Department of Agriculture has adopted this procedure for its practice under the Packers and Stockyards Act, the Toxins Act, and the Federal Import Miilk Act. 1 F.R. (D.I.) 1577, 1578, 1579. 
reduce the evidence to manageable proportions. The disadvantage is that the procedure frequently takes a good deal of time. Moreover, many lawyers fail to take advantage of the opportunity to present exceptions to the report, and much of the value of the procedure as a definition of the issues is lost. This might perhaps be remedied by requiring the parties to plead to the report and to assume that all findings not specifically denied are to be taken as true.

The alternative procedure, under which the examiner's report, if any, is not circulated among the parties, and no opportunity is given for exceptions, seems inferior; yet it is surprising that so many agencies still continue to follow it. An investigation of the reasons why the apparently preferable practise has not been universally adopted would be instructive; it may be merely ignorance or inertia, or it may be that conditions peculiar to some agencies make its adoption impracticable or inadvisable.

General procedural principles. It is doubtful whether the time has yet come for the formulation of general procedural principles applicable in all types of administrative tribunals. However, an interesting subject for study is the extent to which the analogies of procedure in the judicial courts may be resorted to for building up a body of administrative procedural rules. The dangers which lurk in uncritical assimilation are revealed in Jones v. Securities and Exchange Commission, ${ }^{00}$ where the Court analogized a stop order proceeding under the Securities Act of 1933 to a suit in equity. Because, in the latter case, the plaintiff possesses the unqualified right to dismiss his bill unless some prejudice will result to the defendant, it was held that a registrant may withdraw his registration statement at will. But since the commencement of an equity suit puts the defendant on notice that he acts at his peril, even though no temporary injunction is issued, it follows that the mere issuance by the Commission of an order to show cause suspends the effectiveness of a registration statement and places on the registrant the risk of being held in violation of the law if he continues to sell securities before the issuance of a stop order. This result seems to be contrary to the explicit terms of the statute, and, if adhered to in the future, will substantially diminish the procedural safeguards which Congress has set up for the protection of issuers of securities against arbitrary Commission action. Yet, despite the unfortunate consequences of procedural analogies in this case, it cannot be doubted that such analogies have their place. When properly applied with full knowledge of the consequences, they may contribute greatly to the building up of administrative law.

Combination of judge and prosecutor. Much of the denunciation to which administrative tribunals have been subjected has been directed against the combination of prosecuting and adjudicative functions in the

99. 298 U. S. 1 (1936). 
same agency. Indeed, many sympathetic students have found this situation disturbing. It may be that these doubts are well founded, but whether they are is now a matter of mere speculation. Has this combination impaired the judicial quality of administrative acts? Would efficiency suffer if the two functions were separated? How expensive would the separation be? These questions must be answered before a definitive solution can be found.

\section{Problems of Enforcement}

Administrative tribunals exist for the purpose of speedy and informed solution of controversies and enforcement of the laws. While the principle of judicial review must be preserved, it is futile to place an administrative order in the category of mere advisory pronouncements. Administrative tribunals are not just mechanical aids to the taking down of evidence. If they were, we could spare a good deal of expense by turning their functions over to masters in chancery. The administrative order must import a sanction even though the imposition of pains and penalties be ultimately entrusted to the courts. The problems of enforcement of administrative orders can best be approached by considering the following categories:

1. Unenforceable orders. A number of administrative agencies have in the past been authorized to issue orders which have no sanction behind them except the force of publicity and public opinion. An outstanding example is the old Railway Labor Board under the Transportation Act of $1920 . .^{100}$ There are also a number of instances in which administrative agencies issue orders which have no primary sanction, but which may become factors in later proceedings leading to enforceable orders. Thus, when the National Labor Relations Board certifies that certain persons are the representatives of employees for collective bargaining purposes, the certification, as such, carries no sanction. ${ }^{101}$ However, if the employer refuses to deal with the certified representatives, a proceeding may be instituted against him for engaging in an unfair labor practice. ${ }^{102}$

A peculiar type of administrative proceeding which does not result in an enforceable order is provided by the Agricultural Adjustment Act. The Secretary of Agriculture may conduct a hearing to determine whether a handler of agricultural commodities is violating an order, the purpose being to determine the facts so as to refer the matter to the Attorney General for appropriate action. ${ }^{103}$ The theory of such a proceeding is

100. See Pennsylvania R. R. v. United States Labor Board, 261 U. S. 72 (1923).

101. Sec. $9(\mathrm{c})$ of the National Labor Relations Act, cited sipra note 25.

102. Sec. $8(5)$ of the Act.

103. Sec. 8(a) (7), Agricultural Adjustment Act, as amended, 50 Sr^t. 246 (1937), 7 U.S. C. A. $\S 608$ (a) (Supp. 1937). 
that the offending party will mend his ways under threat of court proceedings. A similar system is followed under the Pure Food and Drugs Act. ${ }^{104}$

2. Cease and desist orders. The cease and desist order has become a standard type since.its adoption in the Federal Trade Commission Act. ${ }^{105}$ Its distinguishing feature, and a salient defect from the administrative standpoint, is that a violation of the order carries no penalties until the agency applies to a court for enforcement. If the court affirms the order, a violation constitutes contempt of court. The private party may also secure a review of the order by application to a court. The delays of the law often mean that the order remains a brutum fulmen for many months. As a result, this type of order is most ineffective as a protection to urgent public interests.

3. Orders the violation of which is punishable by criminal penalties. When the Interstate Commerce Commission issues an order, it need not apply to a court for enforcement. The private party may secure a court review by instituting a proceeding to set the order aside, but if he does not, any violation of the order subjects him to a severe penalty. ${ }^{100}$ The Securities Act adopts a similar system. If the Commission issues a stop order, a further sale of securities is a criminal offense since it constitutes a sale without having a registration statement in effect. ${ }^{107}$

4. Licenses. A licensing system constitutes a most effective enforcement method, for one can not do business until he secures a license. This means that he must undergo administrative scrutiny before he begins operation, and since revocation of the license means the loss of a valuable privilege, violations are apt to be rare. The disadvantage of a licensing system is that the withdrawal of the license may be too drastic a sanction; a minor infraction may lead to the destruction of a man's business. The system is best adapted to situations where the government extends a privilege the withdrawal of which will not amount to economic death. Thus, the Bituminous Coal Commission is empowered to approve the formation of marketing agencies which are exempt from the antitrust laws. ${ }^{108} \mathrm{~A}$ withdrawal of the privilege will not put any coal producer out of business; it will only deprive him of the privilege of associating with other producers in the disposal of his

104. Sec. 4 of the Act of June 30, 1906, 34 StAT. 769, 21 U. S. C. A. $\$ 11$ (1934).

105. Sec. 5 of the Federal Trade Commission Act, 38 Stat. 719 (1914), 15 U. S. C. A. $\S 45$ (1934). The same type of order is provided for in the National Labor Relations Act and the Bituminous Coal Act.

106. Sec. 16 of the Interstate Commerce Act, 24 Stat. 384 (1887), 49 U.S.C.A. $\S 16$ (1934). The Commission is also authorized to sue for an injunction to compel enforcement.

107. Sec. 5 of the Securities Act, 48 STat. 77 (1933), 15 U. S. C. A. $\S 77$ (e) (1934).

108. Sec. 12 of the Bituminous Coal Act, supra note 60 . 
coal. At the same time the threat of withdrawal of approval is a far more effective sanction than the threat of a suit to enjoin the disapproved practices.

An interesting application of the license system was found in the original Agricultural Adjustment Act. The Secretary of Agriculture issued blanket licenses to the handlers of agricultural commodities. ${ }^{103}$ This was a curious kind of license since the handler was not required to make application for it. However, if he violated the regulations of the Secretary, he could be deprived of the license and thus put out of business. The system proved to be unsuccessful and was replaced by a system of orders enforceable by injunction and criminal penalties.

5. Tax penalties. A unique system of sanctions is provided in the Bituminous Coal Act. The statute levies a tax of $19 \% / 2 \%$ on the sale price of coal. A producer who adheres to the "Bituminous Coal Code" is exempt from the payment of the tax. If he violates the provisions of the code, the Commission may revoke his membership in the code. During the period when he is out of the code he must, of course, pay the $191 / 2 \%$ tax, and, if he applies for reinstatement, he must pay, in addition, double the amount of the tax on the coal sold in violation of the code. ${ }^{110}$ Apparently the hope of those who devised this system was that it would operate as an automatic penalty and one which was exactly proportioned to the offense. It seems unduly cumbersome, and only time can tell whether it will be effective.

The foregoing list of enforcement devices is not exhaustive, but it will suffice to show the multifariousness of the problem. It will require intensive study to determine how all of these devices work out in practice and how a more orderly system of enforcement can be devised.

\section{A Few Suggestions for the Future}

The purpose of this discussion has been mainly to point out a number of the directions for future investigation. Any informed reader will immediately call other problems to mind. Those which are here mentioned seem to me the most pressing and the most likely to yicld fruitful results to the student. In a field of this kind, research can best be conducted along institutional lines. The nature of the problems and of the materials is such that uncoordinated efforts can bring forth only relatively meager results. With some hesitation, I would suggest the following program.

Individual research along the lines begun by Henderson and Sharfman should, of course, be continued intensively. Research of this type requires fairly liberal subsidy, and it is to be hoped that the Commonwealth Fund

109. Sec. $8(3)$ of the Act of Mray 12, 1933, 48 Stat. 35.

110. Sec. 5 of the Bituminous Coal Act, supra note 60 . 
will continue to finance projects of this kind. Such researches must, however, be coordinated, the individual scholars brought together to exchange ideas, and general principles discussed with informed members of the profession. The coordination could be accomplished through the American Law Institute. At the same time the Institute should consider the support of research projects requiring the cooperative efforts of a number of scholars. I certainly do not suggest any "restatement" of administrative law. But I would urge that a long range program for the preparation of recommendations for improvements in administrative organization and procedure be set afoot.

The practical application of the findings and recommendations of scholars requires some sort of governmental action. It is a fine thing to erect landmarks, but they fail of their purpose when navigators have no eyes for them. It would not be advisable to draw up a comprehensive code for passage by Congress. The preferable, and perhaps the only practical, course is to set up an agency charged with the duty of investigation and experimentation. I would suggest for this purpose the creation of a Conference of Senior Law Officers of the various agencies. Such a body would be in an excellent position to secure an integrated view of the system of administrative justice and should be able to make informed recommendations for improvement in procedure. This body could be entrusted with the duty of keeping in touch with the researches of scholars. Its chief duty would be the preparation of rules of practice for the various agencies; it could put into effect all sorts of minor improvements which are badly needed; it could undertake the publication of a central collection of administrative decisions; it could adopt devices for limiting the size of the voluminous appellate records which administrative proceedings now produce.

This body could go farther and experiment with changes in organization. For example, it could be authorized to arrange for an interchange of trial examiners among the various agencies. If a body of roving trial examiners could be gradually brought into being, two advantages would result. The examiners would gain experience in the procedure of various agencies and would act as critical and unifying agents. More important, the loosening of the ties between the examiner and the particular agency which employs him would breed a greater spirit of impartiality and take some of the sting out of the complaint that administrative agencies confuse the functions of judge and prosecutor.

In short, the Conference here suggested could undertake many of the functions of a supreme administrative court without necessitating the creation of a huge new machine and without impeding the operation of a system which, whatever its faults, is the creature not of theory but of experience and hence not lightly to be disturbed on the basis of untested assumptions. 